New Theatre Quarterly

http://journals.cambridge.org/NTQ

Additional services for New Theatre Quarterly:

Email alerts: $\underline{\text { Click here }}$

Subscriptions: $\underline{\text { Click here }}$

Commercial reprints: $\underline{\text { Click here }}$

Terms of use : $\underline{\text { Click here }}$

\title{
Embodying, Imagining, and Performing Displacement and Trauma in Central Europe Today
}

Phillip B. Zarrilli

New Theatre Quarterly / Volume 24 / Issue 01 / February 2008, pp 24 - 40

DOI: 10.1017/S0266464X08000031, Published online: 30 January 2008

Link to this article: http://journals.cambridge.org/abstract_S0266464X08000031

How to cite this article:

Phillip B. Zarrilli (2008). Embodying, Imagining, and Performing Displacement and Trauma in Central Europe Today. New Theatre Quarterly, 24, pp 24-40 doi:10.1017/S0266464X08000031

Request Permissions : $\underline{\text { Click here }}$ 


\title{
Phillip B. Zarrilli
}

\section{Embodying, Imagining, and Performing Displacement and Trauma in Central Europe Today}

\begin{abstract}
This article provides an illustrated description and analysis of Speaking Stones - a collaborative performance commissioned by Theatre Asou of Graz, Austria, with UK playwright Kaite O'Reilly and director Phillip Zarrilli as a response to the increasingly xenophobic and reactionary realities of the politics of central Europe. The account interrogates the question, the dramaturgical possibilities, and the performative premise which guided the creation of Speaking Stones. Phillip Zarrilli is internationally known for training actors through Asian martial arts and yoga, and as a director. In 2008 he is directing the premiere of Kaite O'Reilly's The Almond and the Seahorse for ShermanCymru Theatre and the Korean premiere of Sarah Kane's 4:48 Psychosis. He is also Professor of Performance Practice at the University of Exeter.
\end{abstract}

Creating and Performing a 'Post-Dramatic' Psychophysical Score for Speaking Stones: images, voices, fragments . . . from that which comes after

Perhaps we are like stones ... our own history and the history of the world embedded in us. Susan Griffin, A Chorus of Stones ${ }^{1}$

Speaking Stones: images, voices, fragments ... from that which comes after was commissioned by Theatre Asou ${ }^{2}$ of Graz, Austria, as a response to the increasingly xenophobic and reactionary rhetoric and realities of contemporary Austrian politics - exemplified by Jörg Haider of the Freiheitliche Partei Österreichs (Austrian Freedom Party). With original text by UK playwright Kaite O'Reilly, Speaking Stones was commissioned as a response to the contemporary issue of the displacement of peoples within central Europe, but with an eye on an often unspoken past: the Holocaust as it was played out in Nazioccupied Austria during the Second World War - an often unacknowledged, seldom discussed, and therefore 'hidden' history.

The performance score was devised and created between Theatre Asou's home location in Graz in the south of Austria and my permanent studio in Wales during three twoweek periods of intensive work between April and September 2002. Speaking Stones premiered (in German) on 12 September 2002 at Theatre im Palais, Graz. The original performance score was revised when the production was re-rehearsed for a second set of performances in an underground quarry in Aflenz, Austria, from 27 to 30 November 2002. The English premiere of the revised performance score was performed in Wroclaw, Poland, in 2003 at the invitation of the Centre of Studies on Jerzy Grotowski. A fourth staging (in German) took place in the Aflenz quarry in 2004 as part of the first official exhibit of the history of the quarry.

Theatre Asou invited me to direct and codevise the project alongside playwright/ dramaturg Kaite O'Reilly and the company. ${ }^{3}$ The process was planned as a collaborative interrogation of a question, a dramaturgical possibility, and a performative premise.

- THE QUESTION: in circumstances of the displacement and traumatizing of peoples, what fragments, images, and/or voices of the past might be disclosed if the environment within which violence and trauma are propagated could speak: 


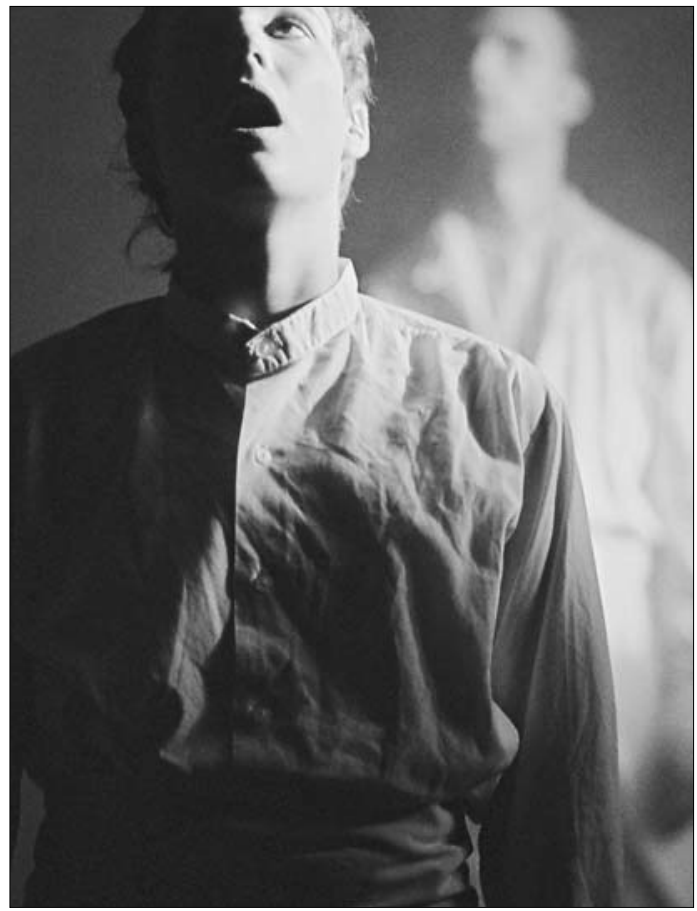

1. 'Bewilderment' (photo: Nina Herlitschka).

i.e., what would happen if 'stones' could 'speak' and 'hidden' histories be revealed?

- the DRAMATURgical possibility: how might a fragmentary, non-narrative, psychophysical performance score be devised and assembled which could both evoke and provoke a synergy between present realities in central Europe and historical memories? 4

- THE PERFORMATIVE PREMISE: how might the psychophysical process I have developed over the years through training actors in Asian martial arts and yoga be applied to a fragmentary, non-narrative, image-based performance score that would juxtapose quite different performance styles ranging from non-verbal psychophysical structures to those containing fragments of realist text?

This essay is an analysis of the process used to answer these questions in practice through performance.

Two primary resources influenced our performative interrogation of issues of displacement and trauma as well as our creative process - Elaine Scarry's reflection on the phenomenology, experience, and problematic representation of torture and pain in her seminal book, The Body in Pain, ${ }^{5}$ and $A$ Chorus of Stones, Susan Griffin's often poetic reflection and uncovering of two parallel histories: the development of the nuclear industry in the US, and the firebombing of Dresden during the Second World War - all the more horrible because these histories have remained hidden in personal and collective silence and/or denial.

In keeping with the nature of the hidden histories she is unearthing, Griffin's writing strategy is indirect and suggestive - 'I am not free of the condition I describe here. I cannot be certain how far back in human history the habit of denial can be traced..${ }^{6}$ Griffin asks her reader:

How old is the habit of denial? We keep secrets from ourselves that all along we know. . . . All history is taken in by stones ... stones record history. The hard surface of the stone is impervious to nothing in the end. The heat of the sun leaves evidence of daylight. Each drop of rain changes the form; even the wind and the air itself, invisible to our eyes, etches its presence. ... I am beginning to believe that we know everything, that all history, including the history of each family, is part of us, such that, when we hear any secret revealed, a secret about a grandfather, or an uncle... our lives are made suddenly clearer to us, as the unnatural heaviness of unspoken truth is dispersed. For perhaps we are like stones; our own history and the history of the world embedded in us, we hold a sorrow deep within and cannot weep until that history is sung. ... We forget that we are history. We have kept the left hand from knowing the right. ... We are not used to associating our private lives with public events. Yet the histories of families cannot be separated from the histories of nations. To divide them is part of our denial. ${ }^{7}$

Griffin astutely observes how 'by denying the truth of an event, one gains the illusion of control' ${ }^{8}$ War produces events and realities often denied, some parts of which are intentionally kept 'away from understanding'. ${ }^{9}$ We are all able to find ways 'of standing outside ourselves in ignorance'. ${ }^{10}$ How might we attempt to give voice in performance to something long denied? 


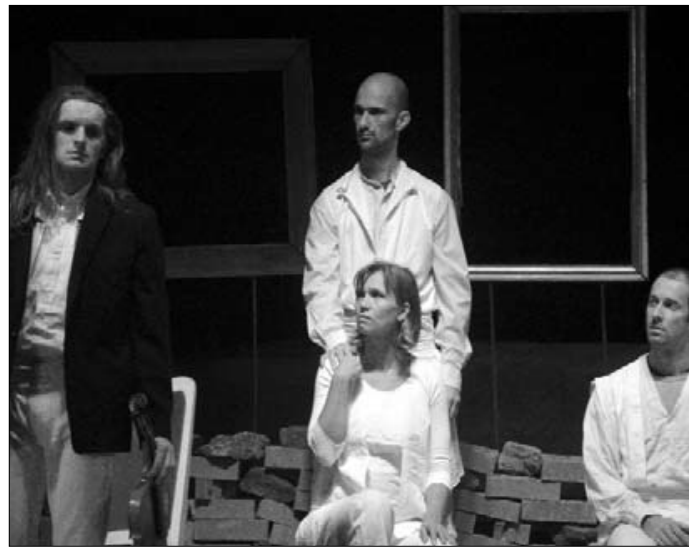

2. 'Leaving' (photo: Phillip Zarrilli).

Forced displacement of a people inflicts direct physical pain and/or severe emotional trauma on its target. But as Scarry explains,

Physical pain has no voice, but when it at last finds a voice, it begins to tell a story. . . . Physical pain does not simply resist language but actively destroys it, bringing about an immediate reversion to a state anterior to language, to the sounds and cries a human being makes before language is learned. . . . Why pain should so centrally entail require, this shattering of language [is made apparent] ... by noticing the exceptional character of pain when compared to all . . . other interior states. ... Our interior states of consciousness are regularly accompanied by objects in the external world. . . . We do not simply 'have feelings' but have feelings for somebody or something, that love is love of $x$, fear is fear of $y$, ambivalence is ambivalence about z. ... Moving through the human interior, one at last reache[s] physical pain [which], unlike any other state of consciousness has no referential content. It is not of or for anything. It is precisely because it takes no object that it, more than any other phenomenon, resists objectification in language. ${ }^{11}$

For Scarry, 'physical pain . . . is languagedestroying', and is 'made visible in the multiple and elaborate processes that evolve in producing $i^{\prime}{ }^{12}$

Given the often denied and/or hidden histories in which we are all complicit and the language-destroying nature of extreme states of pain and trauma, the dramaturgical possibility of the project is reflected in the subtitle of Speaking Stones: 'images ... voices ... fragments from that which comes after'. We did not set out to create a conventional modernist dramatic text or theatre performance that addressed our question through narrative or that followed the journey of one or more specific characters within a specific set of historical circumstances. Rather, similar in some ways to Griffin's writing strategy in $A$ Chorus of Stones, we set out to create an imagistic, impressionist, fragmentary performance score by creating a set of traces - like those in an etching. As Griffin observes,

a story is told as much by silence as by speech. Like the white spaces in an etching, such silences render form. But unlike an etching in which the whole is grasped at once, the silence of a story must be understood over time. ${ }^{13}$

Offering not 'a' story but 'fragments' or 'traces' of stories, the performance score required sufficient 'white spaces' to montage and thereby render images and voices that might reflect denial, trauma, and/or pain's lack of referential content, and that might create resonances between socio-political realities and historical memories for a contemporary central European audience.

We decided to assemble and shape the performance score from three types of sources/ stimuli: (1) performance structures devised from non-verbal psychophysical work with states of being/doing, images, and music; (2) fragments of text and sign-language authored by Kaite O'Reilly and generated from her experience in the former Yugoslavia during the war; and (3) additional 'found' or 'authored' text and music brought in by the ensemble or from our research. ${ }^{14}$ These sources and strategies would then be shaped into a montage whose underlying aesthetic was to be textured as a weaving - the traces of an image or fragment of text in one structure might have resonances via juxtaposition and/or tension with the traces of another.

From my directorial perspective, what was important was providing a set of aesthetic and experientially stimulating traces and fragments of trauma and displacement that over the duration of the performance would cumulatively create the warp and weft of a journey through these disturbing realities, with associations pointing both to the past and present in central Europe. 
The performative premise through which we created the performance score is best considered as a question. What happens when actors embody non-verbal 'traces' of memory like those embedded in stone, i.e., the non-verbal 'white spaces' of a performance etching? To address this question practically, we made use of:

- the nuances of a heightened sensory awareness the actors optimally embody via immersion in the principles and techniques of psychophysical training through Asian martial arts and yoga I have developed since 1976, and to which the company as a whole was first introduced in 1998-99; ${ }^{15}$

- the application of this training and its principles to what I call 'structured improvisations' - an increasingly complex set of psychophysical tasks in which the actors directly apply breath control and deployment of their sensory awareness, visual focus, and attentiveness absorbed from psychophysical training - for example, the actors sit in chairs in a line and on each half-breath (in-breath; out-breath) shift their external gaze/focus between a set of three points: directly ahead but slightly raised, to a place on the floor approximately five feet ahead, or to one of the other actor's eyes; ${ }^{16}$

- inspiration drawn from two contemporary Japanese sources - the work of playwright/director Ota Shogo's 'Station Plays' with their non-verbal scores, 'slowed down everyday movement' with stories that are always present but just not heard, ${ }^{17}$ and the image-based work of Japanese butoh, especially the dancer/ choreographer Kazuo Ohno, such as in The Dead Sea.

We intentionally did not want to limit the performance to one specific mode or style. While there needed to be overall coherence both in dramaturgy and aesthetic, we were more concerned with what vortices of meaning and experience the audience might experience from traces created not by character, but rather 'figures' or 'personas' placed within performance structures animated by and resonating with tasks and stimuli. ${ }^{18}$ The actors in the company would constantly transform from a figure/persona in one structure to another figure/persona in the next.

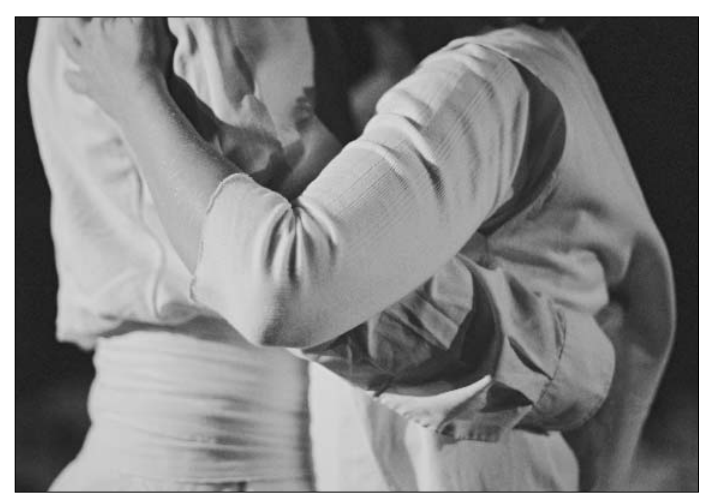

3. 'Leaving': the Dance (photo: Nina Herlitschka).

Before we began work, we knew that some structures would be purely psychophysical and therefore non-verbal, emphasizing engagement in tasks, while others would give voice to text: fragmentary memories, images, recollections, exchanges. Each structure and the etching as a whole would put into play many possible moments of resonance for the audience, but the impact and 'meaning' would depend as much on what the audience brought as what we provided for them.

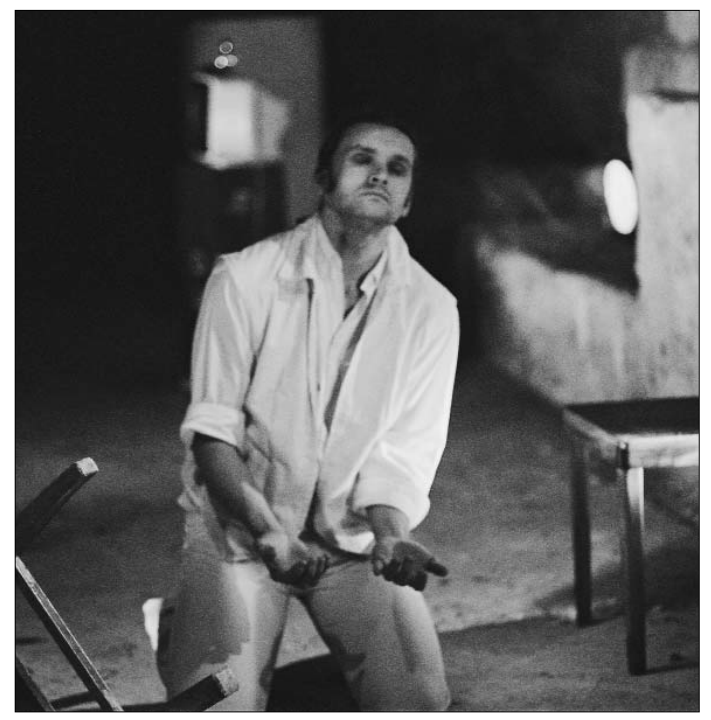

4. 'Footsteps of the Dead' (photo: Nina Herlitschka). 


\section{Speaking Stones: List of Structures}

1. PRESET/SONG

out of the darkness, a lament . . . a mourning song is repeated . . .

2. BEWILDERMENT

faces and palm turned upward . . . trying to see from/through the darkness . . (photo 1)

3. LEAVING

in the darkness, a bewildering laugh . . . suppressed . . . an arrival . . . anticipation . . . a violin ... a couple dances . . . a slap . . . people departing . . . in the dark, a wall of stone collapses into a pile of rubble . . . (2-3)

4. FOOTSTEPS OF THE DEAD

footsteps of the dead processing ... 'silent speaking'(in sign language) . . . then recessing ... (4)

5. INTERNMENT

internment with strangled syllables . . watching Dallas . . soldiers joke . . . (5)

6. MARCHING

marching feet . . . an Austrian folk song sings of the beautiful mountains . . .

7. UNITED FUCKING NATIONS

fragments of stories from 'the United Fucking Nations' . . . (6-7)

8. SEMIOTICS OF ZERO

a 'lecture' . . the semiotics of zero to a Bach cantata . . (10)

9. CHAIR STONES

some bodies, compressed to stone, speak . . others remain silent . . (11)

10. INTERROGATION

questions are asked ... no answers given ...

11. WHY DID YOU LEAVE

more questions are asked . . . a final sepia-orange image (12-13)

\section{Creating the Score}

Initial work on devising and developing specific performance structures began during a two-week period in Graz in April 2002, continued in August in Wales, with a third set of rehearsals in Graz. ${ }^{19}$ Our point of departure for the creation of a structure varied from embodiment of a psychophysical state of being/doing and/or one or more images in a progression, to text authored by Kaite O'Reilly, to a piece of 'found' text. Whatever the beginning point, we elaborated and developed a structure by adding and/or juxtaposing music, additional images, embodiment of psychophysical states, and/or textual fragments. As with any devising process, there was a considerable amount of material that we tried out but eventually discarded. Decisions about which fledgling structures we kept was determined by the potential any particular scenario possessed on its own terms and in relation to the dramaturgy of the etching as a whole.

By the time of the initial set of performances at Theatre im Palais in September 2002, we had developed a provisional performance score with twelve structures. After the first few performances it became clear that we should cut what was then the final structure ('Rubble'), and end the performance with 'Why Did you Leave'. ${ }^{20}$ 'Rubble' provided much too literal an ending - suggesting narrative closure and too closely mirroring the first lengthy structure with minimal dialogue, 'Leaving'. For the final performance of the initial run we tried out this change. Ending with 'Why Did you Leave' accentuated the 'failure' of language central to our early conceptualization of the performance and provided a striking, distorted final image (see figure and discussion below). 


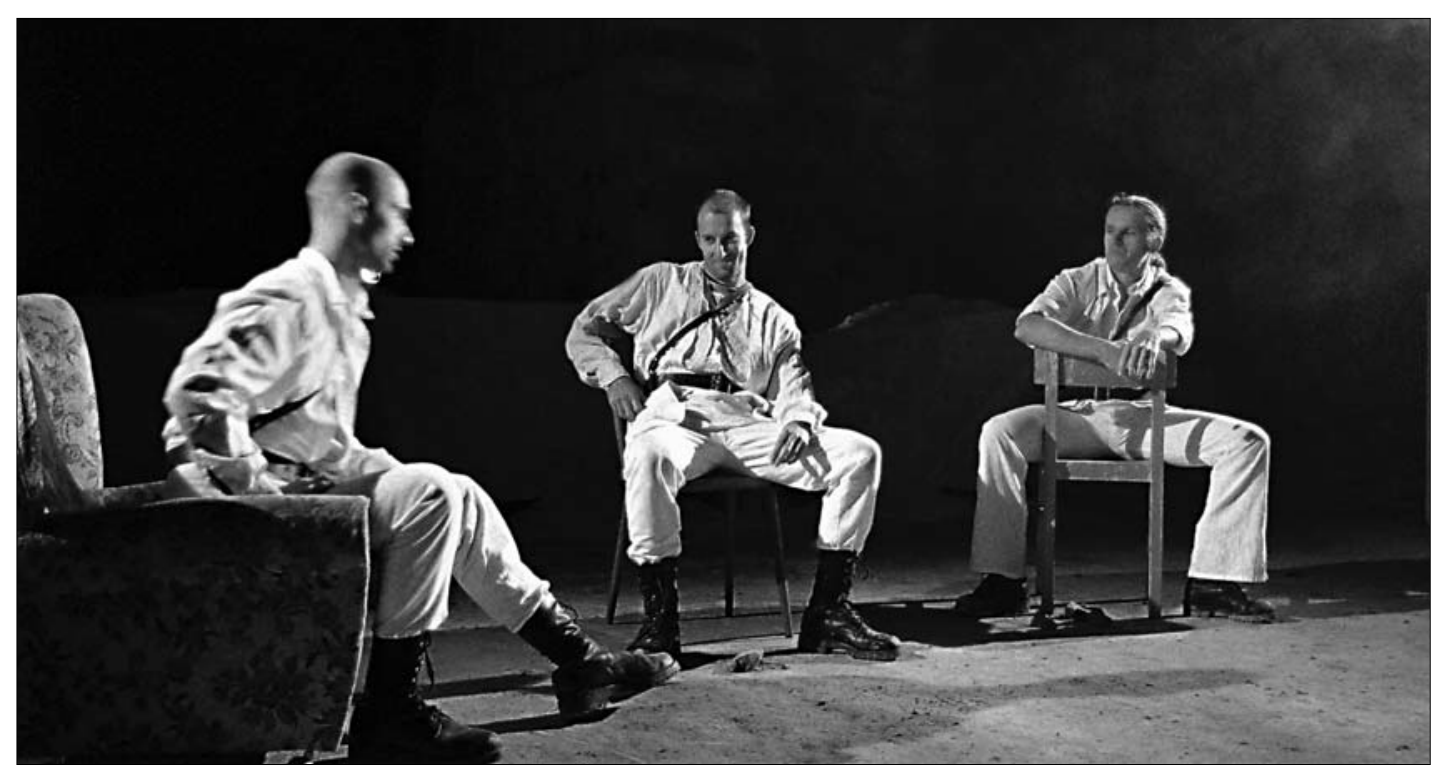

5. 'Internment': the Three Soldiers (photo: Arien Andiel).

Before the second staging of Speaking Stones in Aflenz from 27 to 30 November 2002, we shifted some text and actions from 'Rubble' to 'Leaving', and made other minor adjustments to what became the definitive text and performance score with eleven structures.

Structurally and aesthetically, the performance score for Speaking Stones could be described as post-psychological, or 'postdramatic'. The six actors engage in specific psychophysical tasks and/or deliver fragments of text as they materialize and inhabit a series of 'figures' and 'personas' that are never named. Costumed in a generic assemblage of white/ivory coloured pants, skirts, coats, shirts, vests, and/or waist-wraps with various types of black boots or heavy shoes, all were alike, but each was unique (photos 1-5). These generic costumes allowed the actors to transform from structure to structure without the necessity of being defined as a specific character.

For 'Internment' simple costume pieces were added which provided sufficient additional information for the 'figures' to suggest but not become characters - so that the three women are wearing head-scarves suggests that they are eastern European, and the black belts worn by the three men identify them as soldiers (see photo 5 , above). In
'Internment' and 'United Fucking Nations', the actors-as-soldiers come close to inhabiting conventional 'realist' characters as they speak and act in response to the specific, material circumstances of the conflict in which they find themselves. But in both cases these 'almost characters' are juxtaposed with silent or silenced figures. In 'Internment' the three women appear behind huge stones, attempting to speak, but their initial words 'catch' in the throat - half-said and/or 'strangled' in the act of speaking.

At first, no words are articulated ... only half-guttural sounds. When words eventually come, they are fragments of memory:

A: Her shoe, unlaced beneath the table.

B: When I saw him lying there, he was smiling.

C: It was a silly argument - some cross words.

B: Hands cold, skin thin like paper. Smiling.

A: Old dusty perfume bottles by the mirror.

B: My father never smiled.

A: Her engagement ring beside the sink.

C: The spoon was still in the bowl on the table.

B: His hat was sitting on the hook.

A: The smell of chrysanthemums.

C: We were the only ones to know.

в: The telephone bill came in his name.

C: Her last word was 'no'. 


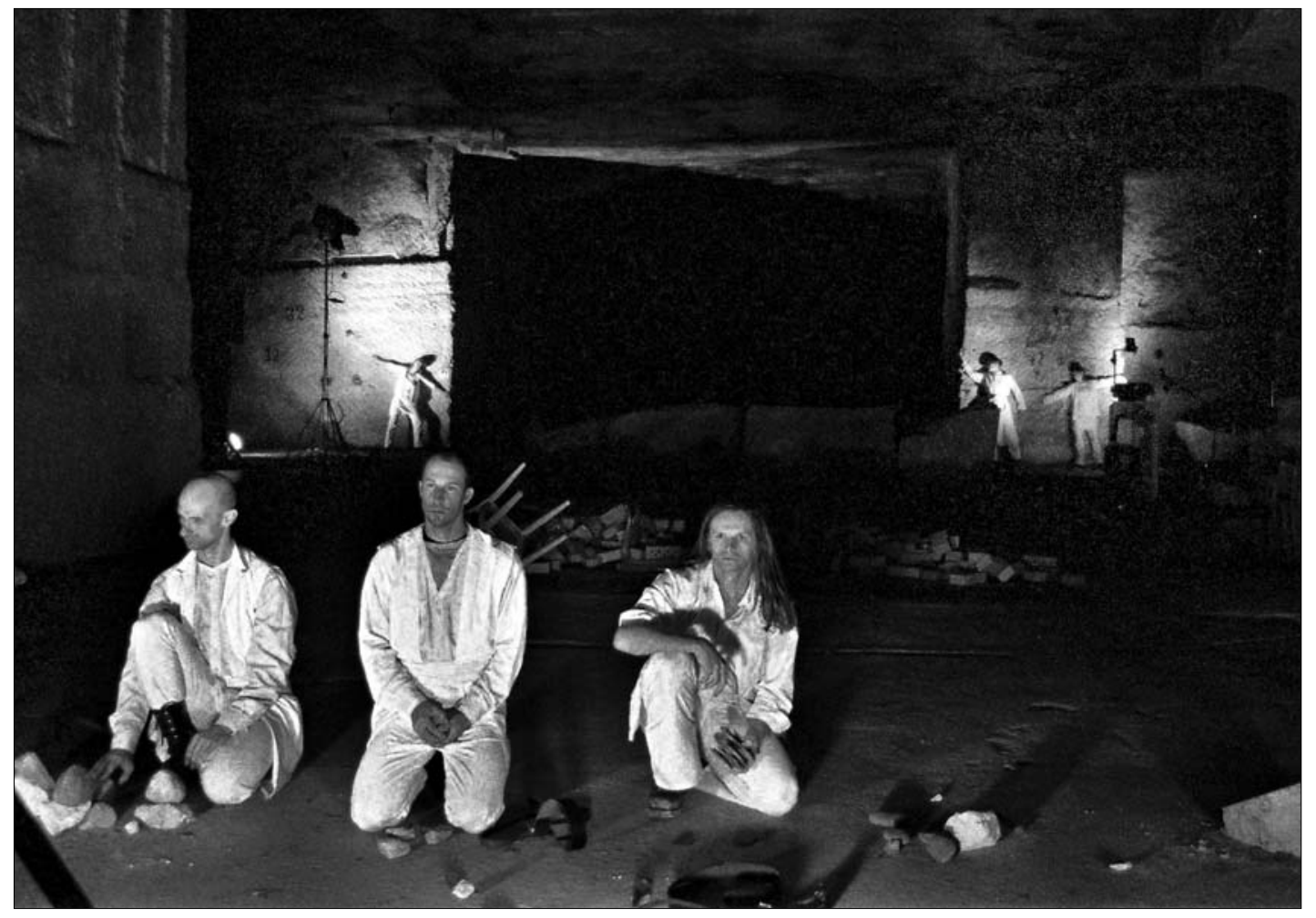

6. 'United Fucking Nations' (photo: Arien Andiel).

During the initial part of 'United Fucking Nations' all six actors engage in repetitive simple tasks with various sizes, types, and shapes of stone - stacking, counting, balancing, listening - while two young men speak in turn directly to the audience without acknowledging the presence or activities of the other actors.

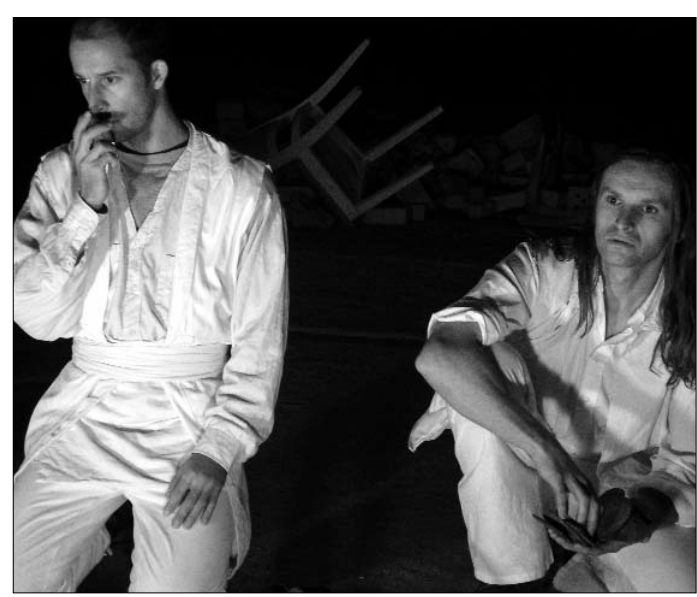

7. 'United Fucking Nations' (photo: Phillip Zarrilli).
YOUNG MAN 1: There were four of us - O'Brien, Pavlovic and the Greek. They called us the United fucking Nations. It was after the last time, that's when I - Four of us. Used kerosene. Old-fashioned. Drag a mattress into the main room - horsehair - still burns - O'Brien splashing the stuff all over the bloody place, running down his arms. Singed the hair off, later. Said that'd teach him, he'd learn. Never fucking did. Smell of pork, burning. I left then. Nothing to it. Change of clothes, plenty on the road, nearly ended up in a collective centre but carried on, due north. North-west. Never had a compass, just walked, followed my nose, smelt my way. Easy. Could have passed as one of them. Often did. Any sign of trouble and I'd just open my mouth and they heard. 'Oh.' Good as a passport, better. Doesn't get wet when you swim.

YOUNG MAN 2: You help yourself to houses along the way. It's not stealing. I'm no thief. Nothing fucking left, anyway. Looted already, the lads before me. See them walking up the road with a telly on their head. Video. CD. Sometimes they'll take the cooker if they've wheels, don't bother with disconnecting, just rip it out, toss a match and there she blows.

YOUNG MAN 1: The things you find. Toys, potato mashers, football trophies. I spent an afternoon 
doing a jigsaw, sticking together these bits of paper. I would've fucking cried if I wasn't laughing. An afternoon doing that bollocks.

That's when you know it's getting to you. Time to get out, boy, and no doubt. A birth certificate, a love letter and a fucking tax bill. Just that. No more.

\section{Performances in the 'Roman Quarry', Aflenz}

While in rehearsals for the initial set of performances in Graz, members of Theatre Asou heard about a vast underground quarry dating from the Roman period nearby, and that an official in Wagna, Walter Gluschitsch, had recently begun opening up the quarry as part of a new, regional cultural initiative. Theatre Asou arranged for all of us to visit the quarry in Aflenz. It was a fortuitous moment. As we entered the space, there was no doubt that all of us immediately ' $\mathrm{knew}^{\prime}$ that this was the most appropriate space in which to perform Speaking Stones. What follows is a brief summary of the history of the 'Römersteinbruch', compiled by the company:

The underground quarry in Aflenz near Leibnitz has a long history. Within the district of Styria, located 35 miles from Austria's second largest city,
Graz, and six miles from Leibnitz, lies the quiet farming village of Aflenz. As one enters the village there is a rolling valley to one's right. No one would know that a massive (8,00o sq metre) ancient underground quarry, whose first use dates from the Roman period, lies hidden within the green hill to the left. Nothing has marked the presence of this quarry since at least the end of the Second World War. Until the last few years the presence of the quarry, and its history, have been kept quiet. It is only when you are directed to walk around the hill along a gravel driveway that you discover, in the midst of a huge wall of rock, two old, massive wooden doors large enough to accommodate trucks capable of carrying quarried stone.

The gravel driveway leads into and through the maze of chambers that constitutes the quarry. The chambers inside vary in size - some are immense (up to ten metres high). When lit, there is a sense of caverns within caverns within caverns. The quiet within is profound. The space is 'alive' to any sound made within its resonant walls and ceilings. The acoustics of the space are vibrant and clear - the stone an excellent transmitter of sound whether spoken/sung, or the sound of breath itself. Equally profound is the lack of light - when all electric lights, torches, or candles are extinguished, one enters a world of absolute darkness. Except inside the immediate entrance, the temperature in the space is a constant eight degrees centigrade year-round.

When the Romans settled in the south and east of Styria, they dug tunnels into the mountain to

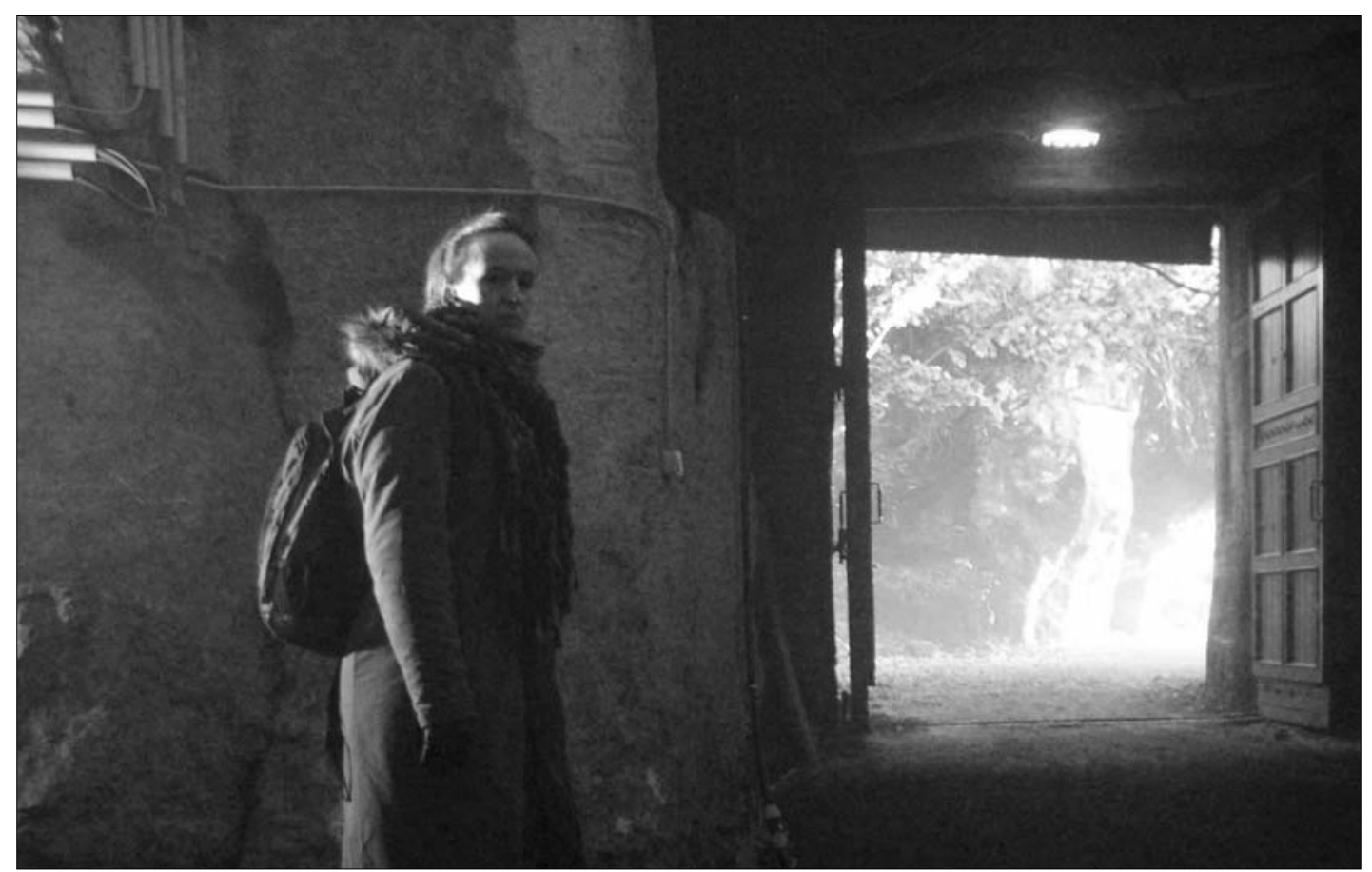

8. Entrance to the quarry viewed from inside (photo: Phillip Zarrilli). 
extract limestone to build an amphitheatre, official buildings, and numerous houses in the nearby settlement, Flavia Solva. Due to the history of the quarry's use during the Second World War, any mention of the quarry was banished from the generally accepted Styrian historical registers. A brief summary of this 'lost' history follows.

During the summer of 1943 as the first allied war planes coming from Italy dropped bombs onto strategically important targets throughout Styria the Nazis began to transfer their war industry underground. In February 1944 the first transport of 201 prisoners from the concentration camp at Mauthausen to the labour camp at Aflenz took place. This was one of seven Styrian subordinate work camps to which prisoners were distributed from the concentration camp at Mauthausen Within a short time the halls of the quarry were changed into a modern machine-works factory. By July 1944 there were already 655 prisoners working underground in the quarry.

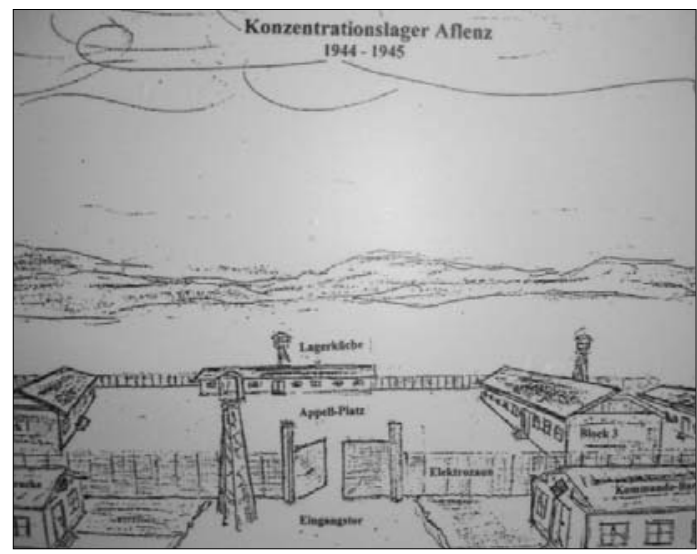

9. The Second World War camp where those working the quarry were incarcerated.

The mortality rate among prisoners was at times very high. Some deceased prisoners were taken back to Mauthausen for cremation, and others buried in a common grave near the camp. By late summer 1944 all the manufacturing equipment was fully installed, and from that time on the prisoners - most from the Soviet Union, Poland, and Yugoslavia - were used for the production of gear wheels and crank shafts.

With the allied advance through Italy the camp was liquidated on 2 April 1945. 467 prisoners were marched off toward the camp at Ebensee. Eight prisoners were shot on the way because of weakness. 49 prisoners tried to escape near Judenburg, but most were caught and shot. On 18 April the remaining 407 prisoners arrived in Ebensee. At the end of the war the Allies dismantled the underground factory. The only evidence of what transpired in the quarry during the war today are a few rusty cable ends sticking out of some concrete.
A few years ago a cultural initiative was established in order to revisit and commemorate the history of the quarry through various cultural events. In 2002 and again in 2004 Theatre Asou was invited by the artistic director of the quarry to present Speaking Stones.

When performed in the Aflenz quarry, Speaking Stones takes place deep within one of the large, central caverns. For the performers and the audience alike, the space itself becomes an actor/activator - both physically and historically. This sense of activation begins with the ten-minute walk from the parking lot, and the journey into this cold, dark, underground environment. As discussed above, Speaking Stones was not created literally to 'tell' the quarry's history, but locating the performance in the quarry allowed its images, voices, and fragments to 'resonate' with that particular history - offering moments and glimpses backward and forward in time and creating a frisson not possible in a formal theatrical environment such as Theatre im Palais.

\section{Embodying the Psychophysical Score}

In the remainder of this essay, I discuss the application of the process of psychophysical training I have developed since 1976 via Asian martial arts and yoga to the creation and performance of some of the specific structures in Speaking Stones. There were three quite different initial points of departure for our work on each structure, as follows:

- psychophysical states and/or imagebased work was the beginning point for the development of 'Bewilderment', 'Leaving', 'Footsteps of the Dead', 'Marching,' and 'Chair Stones';

- short sections of text authored by Kaite $\mathrm{O}^{\prime}$ Reilly served as the beginning point for work on 'Internment', 'United Fucking Nations', 'Interrogation', and 'Why Did you Leave';

- found text (Signifying Nothing: the Semiotics of Zero) was the beginning point for work on 'The Semiotics of Zero'. 


\section{BEWILDERMENT}

'Bewilderment' was developed as a nonverbal, psychophysical score set to background music in which five of the six performers sustain a complex image and awareness throughout the structure - the 'dead' searching for love. The primary psychophysical state of being/doing each actor inhabits is the mouth as a yawning chasm - a black hole reaching back inside one's own body (see photo 1 ).

As the actor allows the jaw to drop open, she senses the open mouth as a deep chasm, and then actively 'enters' this chasm - in effect travelling back inside this 'black hole'. The head is tilted slightly back, so that the eyes are turned upward toward the back beyond of space. But the actor does not focus on an external point; rather, the actor inhabits a dissociated state of awareness produced by 'indirect' focus, i.e., the actor keeps the mind engaged on the task of entering the black hole of the yawning chasm and never focuses with the external gaze. The 'internal' eye keeps travelling back inside.

The actor also keeps attentive to the breath. With the jaw dropped open, the breath becomes audible - sounding as it draws in, and out, to and from the bottom of the black chasm below the navel. The actor actively listens to the breath as it sounds, and allows the breath to become the eyes that are 'looking' for love. Through indirect focus and attentiveness to the breath, the actor senses their mouth-less-ness - a darkness reaching down through the entire body. With each cycle of breath the actor takes that journey of darkness through their body.

With the right hand held palm upward, each actor stands with one foot on the ground and the other foot on a stone, creating a state of slight imbalance. This is intentional. In terms of balance, each actor senses their feet, and constantly attempts to slightly adjust position to find the balance point within the imbalance of the position between the feet. The result of this state of intentional and constant imbalance is the production of a subtle and at first almost imperceptible swaying movement like seaweed underwater moving with the current in a gentle sea. Using a 'chiasmatic' multiple awareness in which the actor's state of being/doing shifts between several heightened states of awareness or images, ${ }^{21}$ each actor's awareness circulates amongst and between the primary image of continuously (re-)entering the black hole of the yawning chasm, making adjustment to one's balance while sensing the feet and thereby producing a subtle swaying, and listening to/absorbing the sound of both the music and the breath as it moves inward and downward, and then outward again - looking ... (again) looking ... (again) looking but never finding.

\section{LEAVING}

The opening part of the third structure, 'Leaving', was developed directly from work on structured improvisations with Theatre Asou. ${ }^{22}$ The actors' actual first names are used throughout the following description of the initial score from which the structure as a whole eventually evolved:

Five actors are seated next to each other - from audience left to right, Chris (holding a violin), Uschi, Gernott, Monika, and Laura. Klaus remains offstage in the darkness behind the seated figures. ${ }^{23}$

Psychophysical score for those seated: Focus ahead. Strong awareness of behind, and through ears/sound... Hear the sound of a clock ticking . . . absorb the sound of time passing ... Keep an extremely strong sense of peripheral awareness of the others present, and of their presence ... Add an additional point of focus up, shifting between ahead and up... Sense in the palm of the right hand the impulse to reach out and grasp with the right hand ... But the impulse 'fails' ... There is nothing there to grasp... Sense the emptiness of the hand which has not touched... sense the 'nothing' in the hand... At some point, if the impulse to look comes, look at the empty right palm.

On a musical cue, Klaus enters from offstage: Looking to first seated figure, Laura, he crosses slowly and stands behind her... looking down to her before him.

Laura: keeping the very strong back awareness, she senses the presence of the standing figure behind her.

Klaus: keeping an extremely strong sense of awareness of the space behind, and of his palms, he places 
a hand on Laura's shoulder. He looks up, ahead. When his hand is placed on her shoulder, Laura absorbs the quality of his touch and senses this fully within.

Klaus senses the next seated figure, looks to Monika, crosses behind her, and places a hand on her shoulder. He looks ahead... .

Repeated for Gernott and Uschi.

This simple series of points of external focus and actions was gradually elaborated. A young woman's laugh fills the darkness of the space, joined by a second woman's laughter until both abruptly stop.

An internal element was added to the playing of the above psychophysical score the extremely strong desire to stay and not to leave, even though all must eventually depart. In playing this structure, it was crucial for the actors to keep a residual awareness of each action as a new impulse shifts the point of focus, or the sensory awareness. Each moment was ideally ' $k$ nit' into the fabric of the whole. Eventually, 'Leaving' was further elaborated with additional actions and text by Kaite O'Reilly that shaped the structure into a series of moments of departure:

Chris stands with his violin in hand, and steps forward. All look to Chris. He stops, starts to look back, and stops. Then he turns back, looking at Klaus and Uschi. He indicates the floor in front. Klaus and Uschi step forward, ready to dance. Before Chris can play, Laura stands, turns away, and takes a step. Chris stops ... looks to her. . . pauses . . looks back to Uschi and Klaus. He begins to play a single note as the couple dance.

KLAUs (as they dance): The one thing never to give is your name.

There is power in knowing a name. They can call you then and when they do, there's no disobeying. You have to answer. No choice in it. (See photo 3.)

Chris stops playing. Turns and begins to exit.

No choice at all.

Uschi steps back. She slaps Klaus. Immediately crosses to pick up her bag. She pauses to share a look at Gernott, who turns away. She crosses to Laura, places a hand on her shoulder, and they exit slowly together.

KLAUS (looking downstage left, as the two women exit into the darkness upstage): My father cleared fields of stones for a penny a bucket. Flint blunted the plough blade - stones made the furrow crooked.
It was backbreaking work, dragging himself and the pails up and down the land to be ploughed. Each year he cleared it, shifting broken stones to the ditch. Every year they came back, rising through the soil as if to taunt him. The earth throwing up its seed from its belly.

Gernott stands, crosses to pick up his suitcase.

My father always said a man was nothing unless he had land. (To Gernott.) All I have is the dirt beneath my fingernails.

Klaus crosses a few steps to a stone. Picks up a stone. My father cleared stones for a penny a bucket. It was a good living.

My father hated stones.

Turns, picks up suitcase. Klaus and Gernott exit together. Monica remains seated, looking ahead.

Lights to black.

While there is one partial story here, it is told by only one speaker. The others present have their own stories, but they remain intentionally untold, unsaid, or about to be said. These unsaid 'silent' stories, marked only by the psychophysical presence of the five actors not speaking, helped to create 'white spaces' within which the one story is told. There was much more that could have been said, but . . . at least at this moment, remains unsaid.

\section{FOOTSTEPS OF THE DEAD}

Like 'Bewilderment', 'Footsteps of the Dead' was developed as a non-verbal psychophysical score set to music - Pachelbel's Canon 11 in D Major. But this often all-too-familiar music was rendered different in an arrangement for traditional Korean plucked instruments, thereby rendering it familiar, but different. The performance score developed for this structure follows:

As lights fade up slowly, through haze, the six actors are revealed as they begin to move... from far within the central cavern towards the audience.

Moving at a glacial pace, always ahead. When they reach the rubble, the rubble is part of the 'problem' that must be solved in the slow progression forward-each footstep an effort.

Awareness and energy: working between awareness of the up through the top of the head, and down through the feet - the space below. Always modulating one's awareness between the up and the down, and maintaining a sense of the behind, 
and 'the before'. Palms slightly up, 'carrying love'... In the act of carrying, always sensing the weight of what is being carried. When the weight is too much in one position, the weight being carried can be shifted. (See photo 4.)

On cue: mouths drop open wide. Entire body becomes the mouth. The footsteps always continuing across the space.

Then mouth closes. Jaw tight. Still keeping the sense of up.

Looking up, turning (some right, some left, wherever the impulse), but still, constantly moving forward, progressing, slowly.

Mouths open again.

FAST SHIFT: Look ahead... freeze, mouth open wide -

SOUND OUT. SILENCE. IN THE SILENCE:

The entire set of awarenesses inhabited thus far are now allowed to gradually 'melt' out of the actor's body. The 'centre' and one's awareness become clear - a fresh slate.

When completely 'melted': using sign-language, but remaining unspoken and unvoiced, in unison the actors 'speak' with their hands: steps (focus out $\times 4$ gestures, right/left/right/left $)$... dead ( focus down, then coffin down with two fingers each side) ... carry (left under right, coming up) ... love (to heart, focus ahead). Slowly, all begin to step backward six steps . . . into darkness.

The embodiment of progressive psychophysical structures such as that described above is not intended to provide the audience with sufficiently detailed semiotic information for a definitive 'reading' of what is witnessed or experienced. Rather, such structures are offered as part of the experience through which associations might arise for the audience. The audience need not 'know' definitively that the actors are 'carrying love'. Nor do we expect the vast majority of the audience to be able to 'read' the sign language. Here the sign-language's primary purpose is not iconic meaning, but another task through which the actors become psychophysically engaged in shaping vectors of energy for the audience's experience.

\section{SEMIOTICS OF ZERO}

This structure's point of departure was the editing of a set of short selections from Brian Rotman's provocative history of attempts to represent and signify 'nothing', zero, or 'the absent' ${ }^{24}$ I edited short selections from Brian Rotman's text into a 'lecture', delivered by Gernott Reiger into a microphone while standing at a podium with an overhead projector next to him. Gernott does not 'play' the 'character' of a lecturer, but rather is 'one who lectures'.

As with my work with actors on a Beckett text, ${ }^{25}$ in delivering the text Gernott's task was to connect as simply as possible to the words in the act of speaking. He was to convey the text not to, but through the actors engaged in psychophysically embodying images associated with the content of the lecture. As when working with actors on Beckett, Gernott simultaneously listens to what he is saying as he speaks - optimally creating an interior loop of awareness resonating with the 'sense' of what is said. This mode of 'speaking' has more to do with engaging and modulating one's interior 'energy' in a qualitative relationship to the act of speaking rather than to 'playing a character'.

While the text of the lecture was our point of departure in this structure, I elaborated a simple, suggestive psychophysical score to work point and counterpoint with the text as both are set to music - Bach's Cantata No. 1 for Altos. The image that becomes visible as the lights come up is of a woman (Monika), seated on the floor next to a man's body (Chris) on the audience side of the pile of rubble. Behind them, seated on three chairs facing different directions amidst the rubble, are two women (Uschi, Laura), and one man (Klaus).

These three figures look off into the distance. They never look at Monika or the man on the floor. In silence, Monika lifts a flat stone in her hand, scoops water from a basin, and lets the water drip into the basin. We hear the drip of the water. The music begins. Absorbing the music with her awareness and allowing the music to 'move' her act of washing the body before her, Monika begins very slowly to 'wash' or 'cleanse' the right hand/arm of the male actor (Chris) lying prone on the floor.

Monika's acting tasks are twofold: (1) to engage with her complete sensual awareness the tactile act of 'cleansing' in which she is 
engaged - allowing this sensual awareness of the feel of the stone, the water, the holding of the hand to 'resonate' within her; and (2) simultaneously to allow the music and text delivered in the lecture to pass through her, and to 'resonate' with her embodied sensual awareness of her first task. She continues this 'cleansing' throughout the performance of the structure. She is absorbing and serving as a vehicle for the text until she comes to a point of rest at the end of the structure, having completed the washing, and crossing the prone figure's arms over his chest.

The three seated actors were given the (impossible) primary task of attempting to embrace 'the absent'. I worked with them on developing a simple semi-improvised, repetitious psychophysical score: the impulse to initiate the first cycle of action was led by a shift in focus from the point ahead, to an unknown point in the space. As soon as they had connected to this new point with their external focus, then the impulse came to 'grasp', 'hold', or 'embrace' - an impulse initiated from the lower tan-tien (in the gut or lower abdomen, about two inches below the navel).

As the 'embrace' is embodied in each cycle, at some point in that psychophysical act of 'embracing' there is a realization that there is nothing there: no one to embrace. At this moment the actor senses 'the absent' one $\mathrm{s} /$ he was about to embrace. Their relationship to the embrace is felt with one's entire psychophysical awareness, but with no overt 'attitude' projected onto the sense of absence ... of nothing being there. At this point in the cycle, the actor stops or pauses, sensing this void through her entire body-mind.

When another impulse to 'find' is generated, the actor looks to another point, initiating a new psychophysical cycle. Each cycle ends in the 'failure' to embrace. The position of the embrace changes with each impulse a choreography in space-time. The second task for these three actors, as for Monika in her acts of 'cleansing', was to absorb and become a vehicle for the text and music.

\section{In silence.}

Washer: hands in lap. Rock in right hand. Looking at crossed arms on body. Hold opening image. Count: 1,001 $\times 5$. Right hand with rock to bowl of water, dip, let drip three times. When the stone is placed on the arm, ready to wash, the music fades in.

SPEAKER: What sort of mark is suitable to inscribe absence?

Three seated figures count 1,001 $\times 3$, and begin first impulse. The actions continue except as noted. Consider the mathematical, purely notational problem that zero addresses. It arises as a gap, an empty region, within the place of notation for individual numerals signifying, in the decimal case, the absence of $1,2,3,4,5,6,7,8$ and 9 . An iconic, mimetic approach to the writing of this absence - take for example that of Babylonian mathematicians for nearly two millennia - might be the use of an empty space to signify it; so that, for instance:

11, 1 1, 1 1 (Writing on overhead projector, demonstrating the problem). One one. One space one. One space space one. Would notate eleven, one hundred and one, and one thousand and one, respectively.

But the scheme has an obvious defect: the right-hand space merges with the blank surface of writing, making 11 ambiguous between eleven, one hundred and ten, eleven hundred, and so on. Moreover, and for the same reason, an empty space is not transportable: unlike the other numerals it cannot be reproduced, written independently of its syntactical presentation with particular numerals, without it merging with the space used to separate words from each other. Signifying absence by absence is not, then, a stable and coherently interesting option for writing down zero. What sort of mark is suitable to inscribe absence?

Movers and Washers pause... Movers freeze and Washers look to Movers ... then freezing . . all listening... .

Speaker places a glass bowl with water on the overhead projector, and continues:

One can depict an absence through a signifier that contains a gap, by a space, an absence in its shape. The most elemental solution, the urmark of absence, is any instance of an iconographic hole; any simple enclosure, ring, circle, ovoid, loop, and the like, which surrounds an absence and divides space into an inside and an outside. Thus, presumably, the universal recognition of ' $\mathrm{o}$ ', ' $\mathrm{O}$ ' or ' 0 ' as symbols of zero. And thus a circle of associations linking zero and 'nothing' ... the absent.

What sort of mark is suitable to inscribe absence?

Movers: continue . . three times . . freezing at end ... Washer dips once, wash three times, put stone in bowl, taking hand they've been washing, and hold it in both hands. 


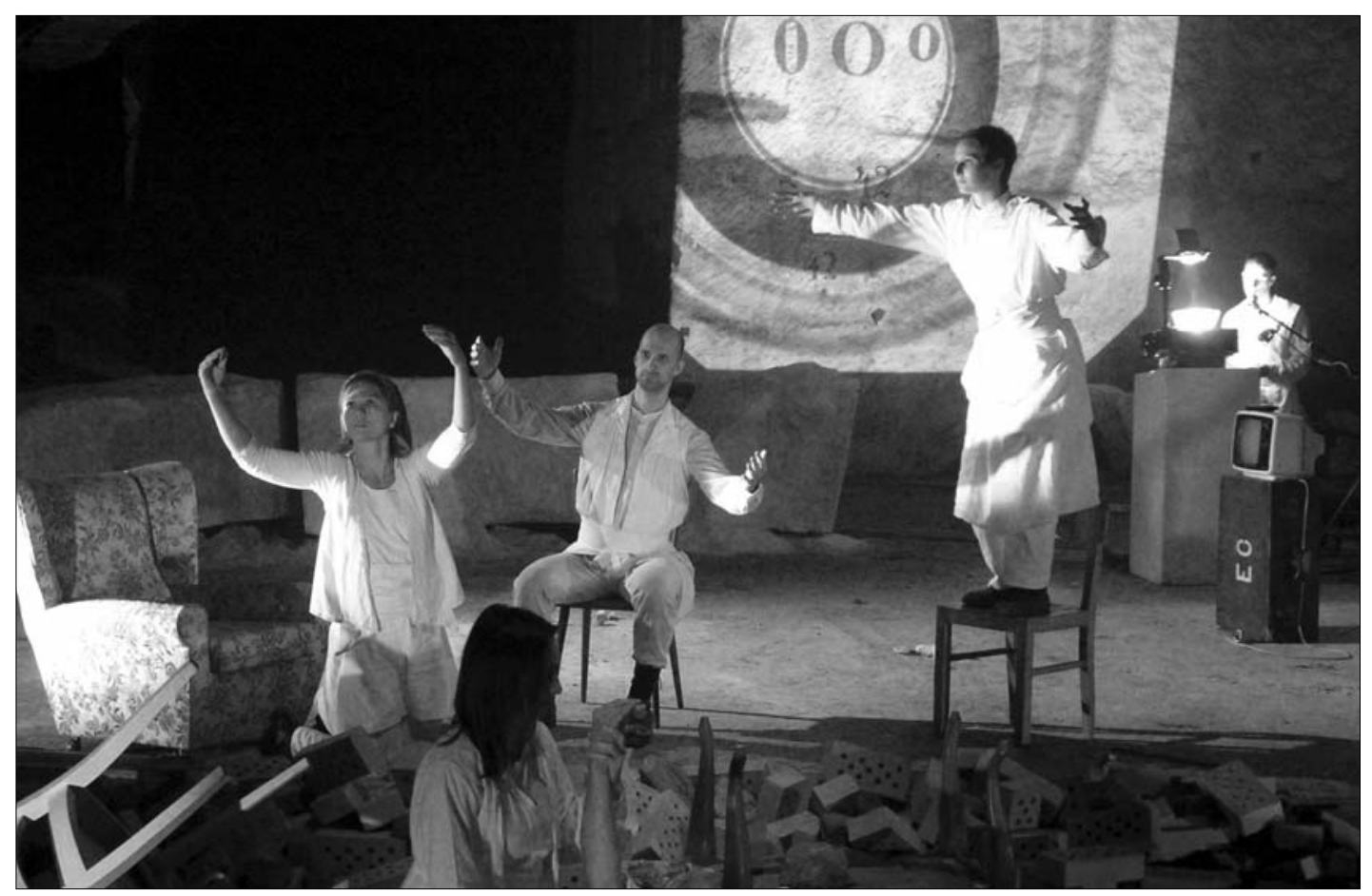

10. 'Semiotics of Zero' (photo: Phillip Zarrilli).

What sort of mark is suitable to inscribe absence?

Monika places Chris's right hand on left. The four figures cross hands over chest, as when they began. Monika looks down. All freeze, suspending their actions as music fades out . . . Pause . . .

The 'psycho' of the 'psychophysical' in the enactment of a scenario like this is not 'psychology', but rather the state of 'resonant awareness' that is generated within one when one fully embodies this simple score and actually listens and is 'sensuous to' the tasks in which one is engaged. During rehearsals, I had to work hard with Gernott not to put character into the delivery of the text and not to attempt to 'play' a lecturer, but rather to become a kind of 'sounding-box' for the speaking of the words and ideas.

For actors used to creating characters, it is often quite difficult to trust the fact that working without character, and with a simple relationship to energy and resonance in the act of speaking, can create sufficient interest and experience for the audience, especially

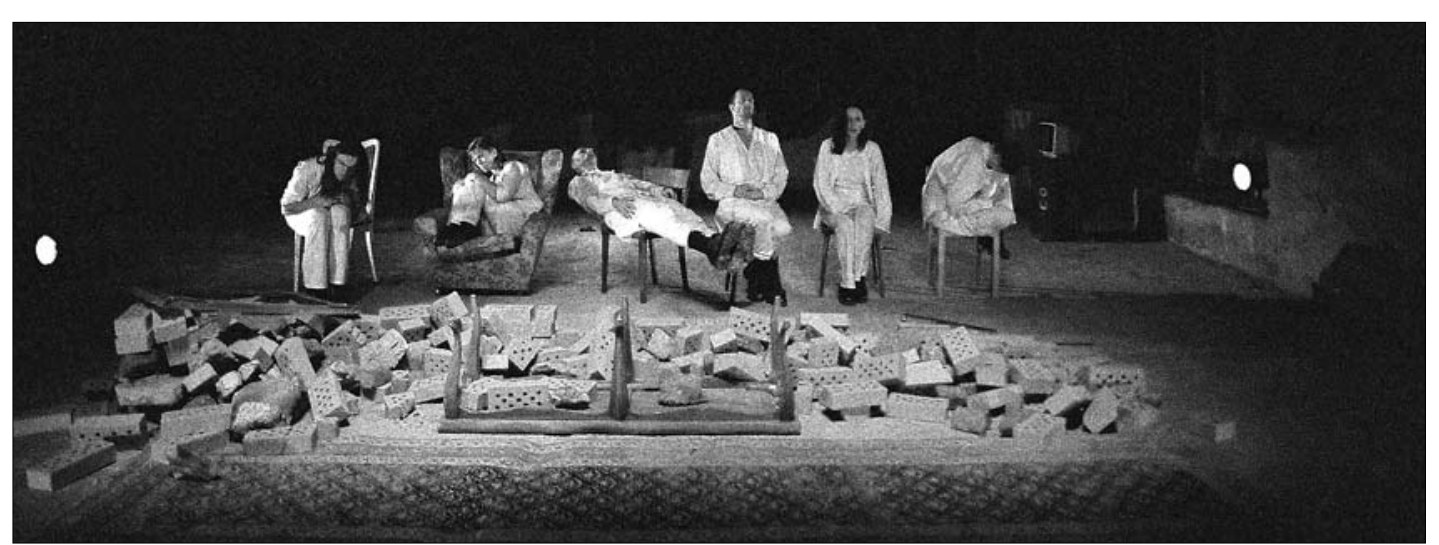

11. 'Chair Stones' (photo: Nina Herlitschka). 


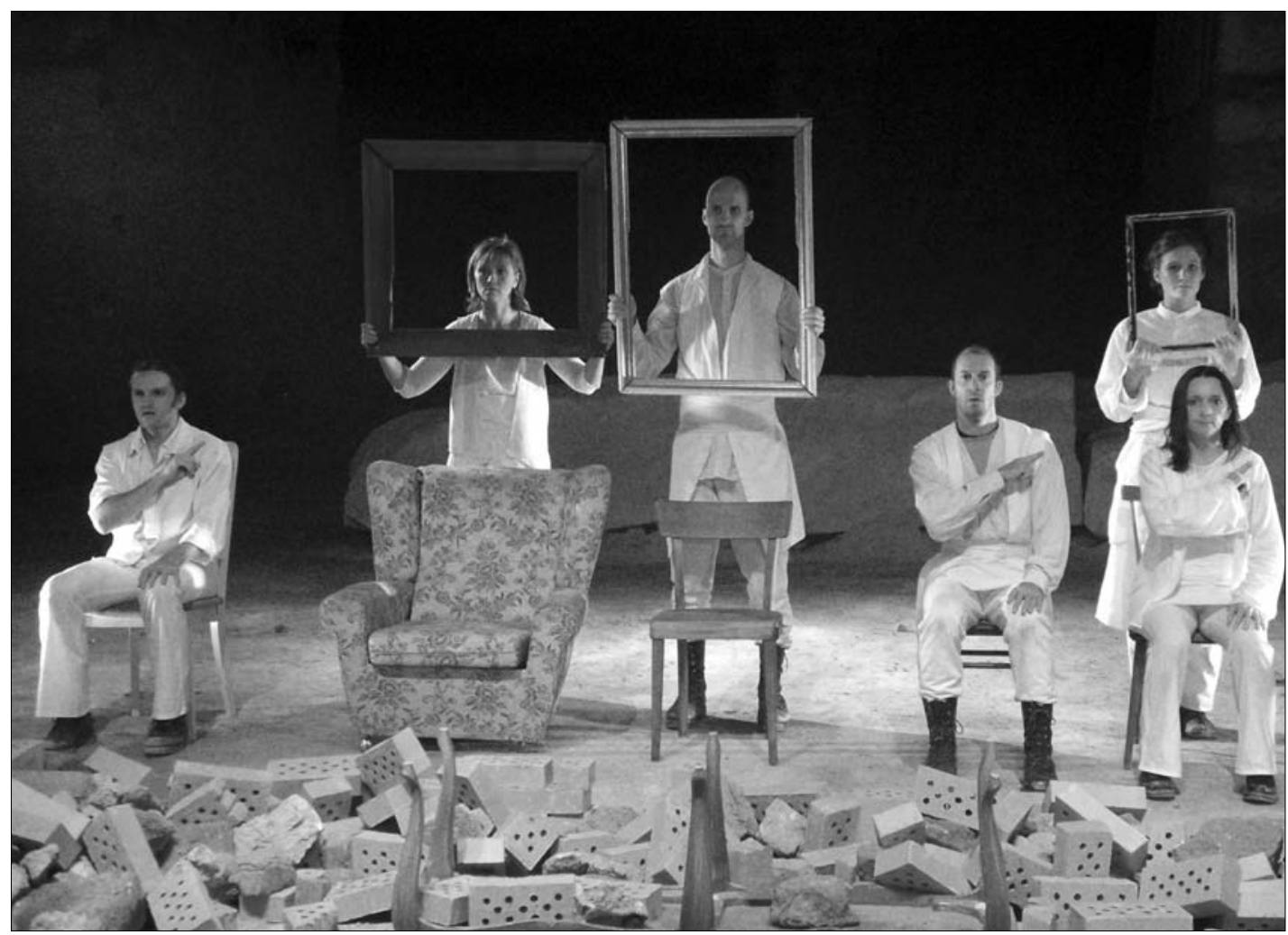

12. 'Words Destroyed' (photo: Phillip Zarrilli).

when spoken text is part of a qualitative montage. Here music, text, and task together create an inner frisson within the actor optimally 'vibrating' them in relation to their work.

\section{WHY DID YOU LEAVE}

The final structure began as a short four-line text authored by Kaite O'Reilly:

Why did you leave?

Why did you not want me?

Why did you not want us?

Words ... destroyed.

We elaborated these four lines into a psychophysical score with progressive action. A still image opens the structure - three actors are seated amidst the rubble, and three actors stand, each literally 'framed' as a picture within the frames each holds.

The image recalls that of 'Leaving' - three empty picture frames are suspended in air behind the seated actors; however, rather than being empty, they now literally frame three faces. In silence, the three seated actors slowly begin to 'speak' each line of the text, but in unvoiced sign language. ${ }^{26}$ We worked the complete psychophysical connection of the actor to the 'saying' of each sign with his entire bodymind.

The actors were encouraged to take time with each word, keeping the other actors in their peripheral awareness so that, at least at the beginning of the structure, their signing was very close to unison. For the second repetition, the three actors continue signing the words, but also begin silently to mouth them. For the third repetition, the three actors standing, each holding a picture frame framing their face, literally drop the frame into the rubble as they join in the delivery of the text. In the final cycle only 'words ... destroyed' are signed/said - their repetition over and again becomes a final 'chorus'. The actors no longer repeat the words or gestures at the same time, but rather all six actors are part of a cacophony of flailing gestures and words - 
suddenly frozen in a final sepia image 'words ... . destroyed'. Suspended in the midst of attempting to speak both with words and sign language, each face and body is distorted in its own way and juxtaposed against the others.

\section{Conclusion}

The psychophysical work in Speaking Stones explored the 'inner action' of vibration/ resonation, not from a psychological/behavioural point of departure, but from a task-based, $k i$ awareness or 'energetics' point of departure. ${ }^{27}$ As with Artaud's vision of the ideal actor, in Speaking Stones the actors optimally became 'athletes of the heart', creating and enacting a 'metaphysics', 'at the nerve ends ... through the skin'. ${ }^{28}$

The fragments of text played an extremely important part in the creation of the potential experience and meaning of Speaking Stones for its audiences, but what was crucial to the limited text used was the type of psychophysical understanding of the embodiment of the images described above, which allowed the resonances of the text, music, and image to be available to the audience via the fully embodied presence of the actors.

\section{Notes and References}

1. Susan Griffin, A Chorus of Stones (New York: Anchor Books, 1992), p. 8.

2. Theatre Asou was founded in 1994. It is a free, independent theatre receiving partial subsidies from the city of Graz and the Styrian government. See <www. theaterasou.at $>$ for further information. I began working with the company as a whole when they participated in the psychophysical training I have developed at intensive workshops hosted by Passe Partout in Utrecht, Netherlands, in 1998. My first production with Theatre Asou was the 1999 production of three Beckett plays entitled, Was Wer? 3 Stücke 3 Raume. In 2002 when we began work on Speaking Stones, the six members of the company included Christian Heuegger, Gernott Rieger, Uschi Litschauer, Monika Zöhrer, Sandra Urbans, and Klaus Seewald. For the 2003-04 productions, Sandra Urbans was replaced by Laura Dannequin (UK/France). The accompanying photographs are from the most recent (2004) production in Aflenz. All quotations from Speaking Stones are from the definitive unpublished English version by Kaite O'Reilly for the November 2002 performances in Aflenz. The German translation is by Frank Heibert with the exception of text used in 'The Semiotics of Zero', translated by George Fischer.

3. Kaite O'Reilly is a well-known, award-winning UK-based playwright and dramaturg. Yard won the 1998

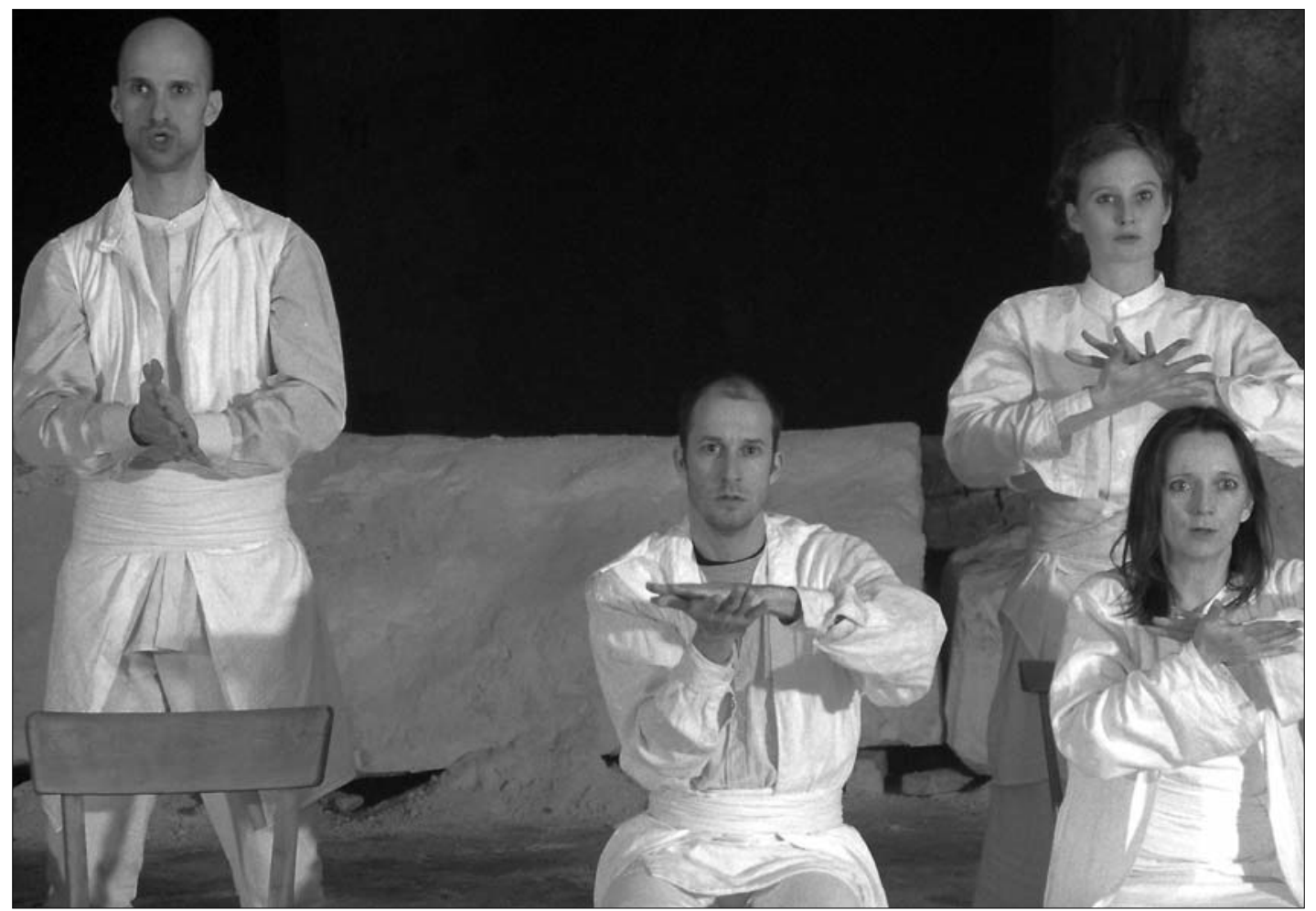

13. 'Words Destroyed': the final sepia image (photo: Phillip Zarrilli). 
Peggy Ramsay Award and premiered at the Bush Theatre London. In a translation by Frank Heibert, Schlacthaus was in repertory at the Maxim Gorky Theatre, Berlin from 2000 to 2002. Belonging was commissioned and produced by the Birmingham Rep in 2000. Perfect was commissioned and produced by Contact Theatre, Manchester, in 2004. Peeling was commissioned and produced by Graeae Theatre, London, in 2002 for a national tour, and received a second staging as part of the British Council showcase at the Edinburgh Festival, 2003. In Praise of Fallen Women premiered in London in 2006. For further information see $<w w w . k a i t e o r e i l l y . c o m>$.

4. The type of performance score we were developing could be called, following the recent English language publication of Hans-Thies Lehmann's Post-Dramatic Theatre (London: Routledge, 2006), 'post-dramatic' in its design and implementation. As explained in more detail below we set out to work against creating any overarching narrative. There would be no fully rounded 'characters' but rather 'figures' or personas with the cas of six constantly transforming from one figure/persona to another. We utilized multiple approaches and styles of performance appropriate to performing specific structures. The audience's associations and responses to the score were intentionally left relatively 'open'.

5. Elaine Scarry, The Body in Pain (New York: Oxford University Press, 1985).

6. A Chorus of Stones (1992), p. 3.

7. Ibid., p. 4-11.

8. Ibid., p. 29.

9. Ibid., p. 32.

10. Ibid., p. 153.

11. The Body in Pain, p. 3-5.

12. Ibid, p. 20, 52.

13. A Chorus of Stones, p. 172.

14. The text used in 'Semiotics of Zero,' was edited by Phillip Zarrilli from Brian Rotman's provocative history of the mathematical concept of 'zero', Signifying Nothing: the Semiotics of Zero (London: Macmllan, 1993). In addition to Kaite O'Reilly's text, O'Reilly also edited and incorporated into the performance score shor contributions from company member Gernott Reiger, a fragment of a poem by L. L. Zarrilli senior, and a few passages from Griffin's A Chorus of Stones for use in other structures.

15. See the following about the training and its principles: Phillip B. Zarrilli, The Psychophysical Actor at Work: a Post-Stanislavskian Intercultural Approach (London Routledge, forthcoming); 'Toward a Phenomenological Model of the Actor's Embodied Modes of Experience', Theatre Journal, LVI (2004), p. 653-66; "'On the Edge of a Breath, Looking": Cultivating the Actor's Bodymind through Asian Martial/Meditation Arts,' in Acting (Re)Considered, ed. Phillip B. Zarrilli (London: Routledge, 2002), p. 181-99; When the Body Becomes all Eyes: Paradigms, Practices, and Discourses of Power in Kalarippayattu, a South Indian Martial Art (New Delhi: Oxford University Press, 1998).

16. A full discussion with examples of 'playing' these simple structures is beyond the scope of this essay. See Phillip Zarrilli's The Psychophysical Actor at Work for a full discussion with examples. Playing these structures
I have developed over the years is essential for actors to absorb the principles of psychophysical training through Asian martial arts and yoga into performance work. While engaged in 'playing' a simple structure such as this, the actors must all maintain a fully embodied awareness of the space behind them, above, to the sides. The principles of the training through martial arts and yoga are intentionally freed from the techniques and forms which are the basis of the ongoing training so that the actor is released from any sense of anticipation or intention in order to see what one 'finds' in playing a structure for which there is absolutely no predetermined meaning, narrative, or conclusion.

17. For discussions of Ota Shogo's work and the principles that inform it, see Ota Shogo, The Water Station, trans. Mari Boyd, Asian Theatre Journal, VII, No. 2 (1990), p. 150-83, and Mari Boyd, The Aesthetics of Quietude: Ota Shogo and the Theatre of Divestiture (Tokyo: Sophia University Press, 2006).

18. For a discussion of the difference between figures or personas and characters see Eelka Lampe, 'Rachel Rosenthal Creating Her Selves', Acting (Re)Considered, ed. Phillip B. Zarrilli (London: Routledge, 2002), p. 291-304.

19. Our work sessions always began with a 90-120 minute psychophysical training session.

20. The titles for each structure were simply descriptive mnemonic devices for use in rehearsals. None of these titles or the descriptions provided below was made available to the audience. It was essential for the audience not to be led in their experience of the performance by the associations that any of the titles or descriptions might generate.

21. See Phillip B. Zarrilli, 'Toward a Phenomenological Model ...' (2004), p. 665-6.

22. See footnote 16, and Phillip B. Zarrilli, The Psychophysical Actor at Work (forthcoming).

23. Since the score was created for the six actors, the names of the actors from the 2004 performance are used to identify specific tasks and/or assignment of lines in quotations from the performance text that follows.

24. Signifying Nothing: the Semiotics of Zero (1993).

25. See Phillip B. Zarrilli, 'Acting "at the Nerve Ends": Beckett, Blau, and the Necessary', Theatre Topics, VII, No. 2 (1997), p. 103-16; Patricia Boyette and Phillip Zarrilli, ‘Psychophysical Training. Physical Actions, and Performing Beckett: "Playing Chess on Three Levels Simultaneously",' Contemporary Theatre Review, XVII, No. 1 (2007), p. 70-80; and Phillip B. Zarrilli, The Psychophysical Actor at Work.

26. Kaite O'Reilly worked with the cast on their performance of the unvoiced signs for this part of the text. For a discussion of her early work in sign-dance theatre, see Kaite O'Reilly, 'What Words Look Like in the Air', Contemporary Theatre Review, XI, No. 3-4 (2001), p. 41-7.

27. There is not space in this essay to elaborate the concept of ki-awareness. For discussions see Yasuo Yuasa, The Body (Albany: SUNY Press, 1987); and The Body, SelfCultivation, and Ki-Energy (Albany: SUNY Press, 1993), and Phillip B. Zarrilli, The Psychophysical Actor at Work.

28. Antonin Artaud, 'Athlete of the Heart', Actors on Acting, ed. Toby Cole and Helen Krich Chinoy (New York: Crown Publishing, 1970), p. 235-40. 